\title{
LEGAL INSTRUMENTS IN THE DEVELOPMENT OF ELECTROMOBILITY IN THE EUROPEAN UNION, WITH PARTICULAR FOCUS ON PLANNING ACTS
}

\author{
Katarzyna Kokocińska*
}

\begin{abstract}
This paper discusses and characterizes actions undertaken for the development of electromobility as part of the incentive policy pursued by the state. In most European countries, development of the electric vehicle market is largely contingent on electromobility policies, but the measures adopted with a view to supporting it do not always yield the expected results. Effectiveness of supporting actions depends on the cooperation of entities which are responsible for development and social-economic cohesion. The situation requires a multi-level approach to the implementation of electromobility development policy, consolidation of actions of various stakeholder groups, and one common direction in the national development of the electric vehicle market. Development planning acts are the very instruments which serve to enhance the efficacy of efforts undertaken jointly by public administration bodies and foster partnership-based relations between state, regional, and local authorities and their social and economic partners.
\end{abstract}

Keywords: planning, development policy, electromobility, legal instruments of support

The article is a result of a fellowship at the CEU San Pablo University in Madrid (December 2019), as part of the author's studies into integrated development programming.

Dr. habil. Katarzyna Kokocińska, Associate Professor, Faculty of Law and Administration, Chair of Public Economic Law, Adam Mickiewicz University Poznań; correspondence address: Al. Niepodległości 53, 61-714 Poznań, Poland; e-mail: katarzyna.kokocinska@amu.edu.pl; https://orcid.org/0000-0002-1008-3538. 


\section{INTRODUCTION}

Among the priorities of state activity affirmed in strategic documents of development policy - including the key mid-term strategy for national development ${ }^{1}$ - considerable emphasis is placed on the need to modernize transport systems by supporting transport which relies on alternative fuels. Thus formulated, the aim of the national development policy corresponds with the activities of the Union institutions, oriented towards climate protection and modernization of the world economy within the paradigm of sustainable development. ${ }^{2}$ New challenges that the European Union and its member state face at this point in the wake of economic or humanitarian crises as well as emergencies such as the COVID-19 pandemic still do not result in major changes to the current policies of EU institutions. Protection of the climate and efforts for sustainable development will remain priorities of the Union, which is endorsed in e.g. the European Green Deal $^{3}$, promulgated in late 2019 and early 2020. EGD is "a new growth strategy that aims to transform the EU into a fair and prosperous society, with a modern, resource-efficient and competitive economy where there are no net emissions of greenhouse gases in 2050 and where economic growth is decoupled from resource use. It also aims to protect, conserve and enhance the EU's natural capital, and protect the health and well-being of citizens from environment-related risks and impact." ${ }^{4}$ The specific goals on which the implementation of the EGD depends include the necessity to modernize transport systems by further reduction of the emission of greenhouse gases and pollution generated by transport,

1 Resolution No. 8 of the Council of Ministers of 14 February 2017 on the adoption of Strategy for Responsible Development to 2020 (with a perspective to 2030), Monitor Polski of 2017, item 260, which replaced the medium-term strategy adopted under the expired resolution of the Council of Ministers of 25 September 2012 on the adoption of the National Development Strategy 2020 (Monitor Polski of 2012, item 882).

2 Communication of the European Commission CARS 2020: Action Plan for a competitive and sustainable automotive industry in Europe of 8.11.2012, COM(2012) 636 final; White Paper. Roadmap to a Single European Transport Area - Towards a competitive and resource efficient transport system of 28.3.2011, COM(2011) 144 final.

3 European Commission, The European Green Deal, COM(2019) 640 final.

4 European Commission, The European Green Deal, COM(2019) 640 final, p. 1. 
as well as encouraging member states to increased effort in developing alternative fuels infrastructure. ${ }^{5}$ Apart from suggesting a framework action plan which, among other things, encompassed assessment of legislative options to boost the production and supply of sustainable alternative fuels for the different transport modes, review of the Alternative Fuels Infrastructure Directive and the Trans European Network - Transport Regulation, and a proposal for more stringent air pollutant emissions standards for combustion-engine vehicles, the Commission stressed the necessity to increase effectiveness of action through improved collaboration, coordination and achieving synergy. Also, one of the priorities of the EU policy adopted in EUROPE 2020. A strategy for smart, sustainable and inclusive growth $^{6}$, namely increased competitiveness and energy security that more efficient use of resources and energy can ensure, will be pursued within the new financial perspective and cohesion policy for 2021-2027. When drafting a range of regulations concerned with the disbursement of funds from its budget, the EU stated that it is a priority to strive for a "more environmentally friendly, emissions-free Europe", which implements in-

5 The Communication from the Commission asserts that "the EU should in parallel ramp-up the production and deployment of sustainable alternative transport fuels." It is expected that "by 2025, about 1 million public recharging and refuelling stations will be needed for the 13 million zero- and low-emission vehicles expected on European roads. The Commission will support the deployment of public recharging and refuelling points where persistent gaps exist, notably for long-distance travel and in less densely populated areas, and will launch as quickly as possible a new funding call to support this. These steps will complement the measures taken at national level". Furthermore, it is declared that "the Commission will propose more stringent air pollutant emissions standards for combustion-engine vehicles. The Commission will also propose to revise by June 2021 the legislation on $\mathrm{CO} 2$ emission performance standards for cars and vans, to ensure a clear pathway from 2025 onwards towards zero-emission mobility. In parallel, it will consider applying European emissions trading to road transport, as a complement to existing and future CO2 emission performance standards for vehicles."

6 Communication from the Commission EUROPE 2020. A strategy for smart, sustainable and inclusive growth, Brussels 2010, COM (2010) 2020 final. There are three underlying priorities of the strategy, expressed in the attributes of the prospective development: smart, sustainable and socially inclusive; all these elements are interrelated and reflect the envisioned social market economy in Europe of the 21 st century. The goals declared there are relevant and representative for all member states; if accomplished, they are expected to enhance economic, social, and territorial cohesion and solidarity. 
ternational agreements, invests funds in the transformation of the energy sector and renewable energy sources as well as addresses climate change. In the proposal relating to long-term financial framework for 2021-2027, the European Commission advanced the ambitious goal of taking climate issues into account in all EU programmes. ${ }^{7}$ The priority in question has become one of goals and challenges of development that Poland is committed to tackle in 2021-2027 .

Union policies with respect to climate and energy are also reflected in legislative efforts. The Electromobility and Alternative Fuels Act of 11 January $2018^{9}$, which implements the solutions adopted in the Directive 2014/94/EU of the European Parliament and of the Council of 22 October 2014 on the deployment of alternative fuels infrastructure ${ }^{10}$, is simultaneously fully consistent with the tenets of the national policy for the development of the electromobility sector. ${ }^{11}$ The enactment constitutes a comprehensive legal instrument which determines the principles governing the development and functioning of alternative fuels infrastructure, stipulates the obligations of public entities in that respect as well as the information obligations, establishes conditions for the functioning of clean transport zones and defines how planning documents should be drafted and implemented. From the standpoint of this study, it is also significant that the legislator determined the manner in which public tasks are to be carried out by the entities obligated to discharge them. Nationals structures are thus required to cooperate with Union institutions; furthermore government-level bodies are to collaborate with territorial self-gov-

7 https://eur-lex.europa.eu/legal-content/PL/TXT/?uri=CELEX:52018PC0375.

8 Assumptions of the Partnership Agreement for 2021-2027 https://www.funduszeeuropejskie.gov.pl/media/76917/zup2021-2027.pdf.

9 Journal of Laws 2018, item 317 as amended, hereinafter as "Electromobility Act".

10 Official Journal of the European Union L 307, 28 October 2014, 1.

11 Piotr Lissoń notes that "...in the light of provisions contained in Directive 2014/94, electromobility (alternatively electro-mobility, or e-mobility; Ger. Elektromobilität, Fr. L'électromobilité) denotes use of electric energy as a source of propulsion of wheeled vehicles or watercraft (vessels or ships) used in inland or maritime transport. However, the meaning of the term is not specified in the definitions in Article 2, Directive 2014/94."; Piotr Lissoń, "Zadania gminy w zakresie elektromobilności," in Prawne i ekonomiczne aspekty rozwoju elektromobilności, ed. Katarzyna Kokocińska, and Jarosław Kola (Warsaw: C.H. Beck, 2019), 57-86. 
ernment units which, for their part, need to encourage private entities to become involved.

Development-oriented efforts also include introduction of an incentive policy, in that the state puts subjectively and objectively varied supporting measures (instruments) into effect to promote the development of a given sector of national economy. As it follows from studies conducted in most European countries, the development of the electric vehicle market largely depends on the policies supporting electromobility. ${ }^{12}$ Moreover, it is noted that the applied supporting measures do not always yield the expected results. ${ }^{13}$ Genuinely effective supporting actions often hinge on an element which the EU strongly emphasizes, namely cooperation of the entities responsible for development and social-economic cohesion. The situation requires multi-level approach to the implementation of electromobility development policy ${ }^{14}$, consolidation of actions of various stakeholder groups, and adoption of one, common direction in the national development of the electric vehicle market. ${ }^{15}$

This paper aims to demonstrate that achieving cohesion of actions undertaken by public administration bodies to promote development of electromobility and integration of efforts to accomplish strategic development goals are not feasible if cooperation is not adequately structured. Here, development planning acts provide the instruments to enhance the efficacy

12 The issue is discussed more broadly by Ivan Kondratenko, "Najlepsze europejskie praktyki w zakresie wspierania rozwoju elektromobilności," in Prawne i ekonomiczne aspekty rozwoju elektromobilności, eds. Katarzyna Kokocińska, and Jarosław Kola (Warsaw: C.H. Beck, 2019), 39-56.

13 See Michał Kania, "Umowy w sprawach zamówień publicznych oraz umowy o partnerstwie publiczno-prywatnym jako forma wsparcia elektromobilności," in Prawne i ekonomiczne aspekty rozwoju elektromobilności, eds. Katarzyna Kokocińska, and Jarosław Kola (Warsaw: C.H. Beck, 2019), 165-190.

14 See Katarzyna Kokocińska, "Spójność działań organów władzy wykonawczej na rzecz rozwoju (na przykładzie sektora elektromobilności)," in Prawne i ekonomiczne aspekty rozwoju elektromobilności, eds. Katarzyna Kokocińska, and Jarosław Kola (Warsaw: C.H. Beck, 2019), 3-16.

15 Recital 14, Directive 2014/94/EU: "Fuels included in the national policy frameworks should be eligible for Union and national support measures for alternative fuels infrastructure, in order to focus public support on a coordinated internal market development towards Union-wide mobility using alternative fuels vehicles and vessels." 
of cooperative actions of public administration bodies and build partnership-based relations between state, regional, and local authorities and their social and economic partners.

For this reason, this study examines the measures to support the development of electromobility while focusing on the instruments such as development strategies, plans or programmes which the doctrine of public law qualifies as means of intervention that serve the state to perform its function of economic planning. ${ }^{16}$

\section{SOCIAL AND ECONOMIC CIRCUMSTANCES OF TRANSFORMATION TOWARDS ELECTROMOBILITY}

The established goals of state policy provide the foundation for implementing a system to support a particular sector; with regard to the electromobility sector, the solutions are determined by the objectives of Union policy. From the EU standpoint, the outcomes of applied supporting measures are a vital matter, whereas their type and nature are dictated by internal, national circumstances (next to economic goals, social and environmental conditions are particularly stressed). The selection of measures (e.g. more socially or economically oriented), their intensity, scope of application, accessibility (public or private entity) follow from the adopted national policy which specifies the goals relating to the development of electromobility. Also, the obligation to pursue Union policy to mitigate climate change bears crucially on the implementation of instruments to support development of electromobility. ${ }^{17}$ However, for certain countries that key objective goes hand in hand with other critical goals, such as reduction of $\mathrm{CO}_{2}$ emissions (Norway), increased economic competitiveness

16 Thus e.g. Kazimierz Strzyczkowski, Prawo gospodarcze publiczne (Warsaw: Lexis Nexis, 2011), $184 \mathrm{ff}$.

17 Mona Hymel, Larry Kreiser, Janet E. Milne and Hope Ashiabor, eds., Innovation Addressing Climate Changes Challenges. Market-based Perspectives, Critical Issues in Environmental Taxation, Volume XX (Cheltenham, UK Northampton, MA, USA: Edward Elgar Publishing Limited, 2018). 
(Germany ${ }^{18}$, France), lower dependence on fossil fuels (the Netherlands) or higher energy security, which the governments of EU states often invoke. ${ }^{19}$

Striving for clean and sustainable transport is declared a priority by most states ${ }^{20}$, and the prospect of reduced pollution and greenhouse gas emissions associated with the electric fleet is the main reason to exchange combustion engine vehicles for their electric alternatives. Nonetheless, studies show that this is not universally applicable, as it has been demonstrated $^{21}$ that in countries where coal remains the principal energy source, using an electric vehicle is more harmful than using a vehicle powered by a combustion engine. ${ }^{22}$ Consequently, the role of electric vehicles in facilitating daily life in large urban centres - cited as a prime cause behind the development of electromobility - loses some of its significance. Still, other advantages of electric vehicles are mentioned, such as reduced noise ${ }^{23}$ and air pollution, all as part of the concept of smart cities in which transport does meet the requirements of sustainability, meaning that it is socially inclusive, environmentally friendly, safe, integrated and technologically oriented. ${ }^{24}$ Public awareness and readiness with respect to transi-

18 Die Bundesregierung, German Federal Government's National Electromobility Development Plan, Berlin 2009, https://www.bmu.de/fileadmin/bmu-import/files/pdfs/ allgemein/application/pdf/nep_09_bmu_en_bf.pdf, last access: 15.8.2020.

19 See: Ivan Kondratenko, "Najlepsze europejskie praktyki w zakresie wspierania rozwoju elektromobilności," in Prawne i ekonomiczne aspekty rozwoju elektromobilności, eds. Katarzyna Kokocińska, and Jarosław Kola (Warsaw: C.H. Beck, 2019), 39-56.

20 Marta Villar Ezcurra, Cambio Climático, Fiscalidad y Energía en los Estados Unidos: Una batería de ejemplos a considerer (Cizur Menor, Navarra: Civitas, 2012).

${ }^{21}$ Lindsay Wilson, Shades of Green: Electric Cars' Carbon Emissions around the Globe; Reducing the environmental impact of road construction Technical Report, ARRB Group Limited: Vermont South, Australia 2013.

22 Marcin Łuszczyk, "Uwagi do planu rozwoju elektromobilności w Polsce," Prace Naukowe Uniwersytetu Ekonomicznego we Wroctawiu, no. 491 (2017): 274-282.

23 Marta Villar Ezcurra, "Noise pollution taxes: a possibility to explore," in Innovation Addressing Climate Changes Challenges. Market-based Perspectives, eds. Mona Hymel, Larry Kreiser, Janet E. Milne, and Hope Ashiabor, Critical Issues in Environmental Taxation, Volume XX (Cheltenham, UK Northampton, MA, USA: Edward Elgar Publishing Limited, 2018), 113-126.

24 Technologies which contribute to the development of smart cities include autonomous vehicles, fast bus transportation or shared mobility in the form of e.g. carsharing, carpooling, ridesharing, ridesourcing. 
tion towards electromobility are also crucial, which necessitates educational action as well.

In view of the environmental, social and economic circumstances, specific categories of public entities in EU member states are obligated to contribute to the development of national infrastructure that enables electricity-powered vehicles to be widely used. In Poland, this includes the obligation arising under Article 32 of the Electromobility Act, which imposes the requirement of developing location plans for publicly accessible charging stations. The legislator also determines a range of tasks associated with public investment in the sector, as well as enjoins public entities to promote it through a policy of model institutions, as central and local administration are obligated to electrify their fleet (Articles 30 and 35). To a considerable degree, obligations relating to electromobility - including those mentioned above - lie with the territorial self-government units, district authorities in the main, which are expected to set up charging stations (Article 60) and establish particular rules of using electric vehicles in road traffic (Article 39). This is due to the fact that district-level public bodies possess competences with regard to planning and regulations, as well as carry out tasks which include provision and organization of services for the community, or traffic organization and management. ${ }^{25}$

Still, the obligatory contribution of public entities to the development of electromobility is not the dominant notion or direction of transformation towards electromobility. According to Directive 2014/94/EU, member states should have the ability to implement its provisions primarily by means of a broad array of incentives and regulatory or non-regulatory measures, acting in close cooperation with entities in the private sector, which should play the key role in supporting the development of alternative fuels infrastructure (Recital 15).

25 Piotr Lissoń, "Zadania gminy w zakresie elektromobilności," in Prawne i ekonomiczne aspekty rozwoju elektromobilności, eds. Katarzyna Kokocińska, and Jarosław Kola (Warsaw: C.H. Beck, 2019), 57-86. 


\section{LEGAL CHARACTERIZATION OF MEASURES (INSTRUMENTS)}

TO SUPPORT THE DEVELOPMENT OF ELECTROMOBILITY

In further disquisition, it is presumed after K. Strzyczkowski that the term "measure of action" (or, alternatively, "instrument") denotes any behaviour that may be within the purview of public administration. ${ }^{26}$ Such a broad approach to the behaviours of administration makes it possible to employ a very capacious legal category which comprises diverse forms of influence that the state (public administration) may exert on the economy. When classifying measures (instruments) that are brought to bear in the domain of economy, they tend to be distinguished into general and individual measures. The first category encompasses measures applicable to the entire economy or particular industry, such as strategies, plans, and programmes. The second includes those measures which are intended or addressed to a specific entity. Next to orders, proscriptions, and fines, measures which have an economic impact are employed increasingly often. Given the perspective adopted here, the development of electromobility is fostered primarily by positive intervention measures, both those intended for specific entities (e.g. economic incentives such as subsidies or grants), as well as general ones, by means of which the state discharges its function of economic planning. It is precisely planning instruments which are given a prominent role in building the EU's alternative fuels market; this matter is discussed in greater detail further on.

Polish legislator follows the universal trend, having recognized the necessity to employ supporting measures with the development of electromobility in mind, and emulating the solutions adopted in other European countries which seek to accomplish the goals of Union policy in this respect. After all, Directive 2014/94/EU allows member states to implement its provisions using a broad range of incentives to launch investment in sustainable transport and support the development of a continuous network of alternative fuels infrastructure in the European Union. ${ }^{27}$ It has

26 Strzyczkowski, Prawo publiczne gospodarcze, $197 \mathrm{ff}$.

27 Supporting measures for the alternative fuels infrastructure are applied in accordance with the rules of state aid contained in the Treaty on the Functioning of the European Union (Article 107 et seq.). 
to be underlined that the pace, the kind and the scope of support differs across most European states, due to which the emergence of the European electric vehicle market is not a uniform process.

The national legislator opted for an intermediate regulation, introducing individual supporting instruments which have an indirect effect on the conduct of its addressees. The measures, referred to as economic impact measures, motivate one to particular behaviours, i.e. behaviours which are deemed desirable from the standpoint of state policy (and goals specified in policy acts). In the doctrine, such a behaviour of the state bodies which intervene into the economic domain to accomplish economic goals is described as regulation through stimulus. ${ }^{28}$

Among the instruments which support the development of electromobility, in other words instruments geared towards the accomplishment of public goals (which in this case means increasing the number of electric vehicles) which have been intended for individual entities (businesses, other enterprises, consumers), financial stimuli are predominant. ${ }^{29}$ Article 51 of the Electromobility Act introduces an amendment to the Personal Income Tax Act of 26 July $1991^{30}$, extending the range of exclusions from tax deductible expenses. In accordance with the amendment, write-offs in respect of wear on passenger car, made pursuant to the rules set forth in Article 22(a)-22(o) of the Personal Income Tax Act, in the part calculated on the value of the car exceeding the amount of PLN 225,000 for passenger car which is an electric vehicle within the meaning of Article 2(12) of the Act, and PLN 150,000 for other passenger cars, are no longer deemed tax-deductible expenses. Also, Article 52 of the Electromobility Act amends the Corporate Income Tax Act of 15 February $1992^{31}$, whose amended Ar-

28 Strzyczkowski, Prawo publiczne gospodarcze, 200.

29 See: Claudia Kettner and Daniela Kletzan - Slaming, "Vehicle taxation in EU Member States," in Innovation Addressing Climate Changes Challenges. Market-based Perspectives, eds. Mona Hymel, Larry Kreiser, Janet E. Milne, and Hope Ashiabor, Critical Issues in Environmental Taxation (Cheltenham, UK Northampton, MA, USA: Edward Elgar Publishing Limited, 2018), 83-97; Celina Kacperski and Florian Kutzner, "Financial and symbolic incentives promote 'green' charging choices," Transportation Research Part F: Traffic Psychology and Behaviour, vol. 69 (2020): 151-158.

30 Journal of Laws of 2018, item 200, 2017, item 2494 and 2018, items 106 and 138.

31 Consolidated text: Journal of Laws 2019, item 865. 
ticle 16(1)(4) excludes write-offs in respect of wear on passenger car, made pursuant to the rules set forth in Article 16(a)-16(m) of the Corporate Income Tax Act, in the part calculated on the value of the car exceeding the amount of PLN 225,000 for passenger car which is an electric vehicle within the meaning of Article 2(12) of the Act, and PLN 150,000 for other passenger cars from tax deductible expenses. The Electromobility and Alternative Fuels Act also establishes preferential conditions for the purchasers of electric and hydrogen-powered vehicles, who are exempt from excise duties. Furthermore, under Article 163(a) of the Excise Duty Act, temporary exemption is granted until 1 February 2021 for hybrid passenger cars, in which electric energy is supplied by connecting to an external source of energy. Another instrument which encourages purchase of electric vehicles is the possibility of obtaining subsidies, whether by entrepreneurs or persons who do not engage in any business activity. It is noted that this form of support most often convinces one to purchase an electric vehicle. ${ }^{32}$ In many European countries, all-electric vehicles are exempt from pollution tax (Austria), vehicle property tax (Bulgaria, Spain), as well as registration fee (France, Greece, the Netherlands). Yet another measure is exemption from road tax, its considerable reduction, or increased limits for amortization write-offs (Czech Republic, Cyprus).

In their efforts to increase the share of electric vehicles on the national market, EU states employ non-financial supporting measures as well. They may not have as great an impact as the financial incentives, but they do influence the decision to purchase an electric vehicle because of the convenience it involves (especially in large urban centres). The most frequently encountered non-financial instruments include the ability to park or use toll roads free of charge, as well as use bus lanes. ${ }^{33}$

32 Petra Zsuzsa Lěvay, Yaniss Drossinos and Christian Thiel, "The effect of fiscal incentives on market penetration of electric vehicles: A pairwise comparison of total cost of ownership," Energy Policy, vol. 105 (2017): 524-533.

33 Norway is widely considered a country whose policy to promote electromobility proves the most successful. The policy was launched in the 1990, as Norway abolished import duties on electric vehicles. Then in 1996, owners of electric vehicles were made exempt from vehicle property tax, while since 1997 persons driving electricity-powered vehicles no longer had to pay on toll roads (chiefly motorways and expressways). In 1999, special registration plates were introduced for electric vehicles, while their owners would not be 
The degree and extent to which financial and non-financial measures are applied depends on numerous factors; in the main these include the capacity of the energy system, the state of road infrastructure or social-economic benefits. It is underlined that an intensive policy needs to be pursued if the aim is to increase the number of alternatively-powered vehicles, enhance their price competitiveness, and create more preferential conditions for their use. The benefits one quotes, such as the anticipated improvement of the quality of life in the cities as a result of diminished air and noise pollution generated by urban transport, development of a technology market with a potential to compete internationally, boosting electric bus segment at enterprise level and the related research-and-development potential, or reduction of overall ownership costs in city transport during the entire life-cycle of a bus, are sufficient reasons for a state to opt for an active policy in that respect. ${ }^{34}$

\section{PLANNING INSTRUMENTS FOR THE DEVELOPMENT OF ELECTROMOBILITY}

Although member states themselves select appropriate supporting instruments and decide on the intensity of their application, Directive 2014/94/EU stresses the need for a coordinated policy of introducing alternative fuels in order to prevent fragmentation of the internal market. It is thus asserted that "coordinated policy frameworks of all Member

charged for parking in urban areas. Another important element of the electromobility policy was partial reduction of the vehicle tax for businesses using electric vehicles, introduced in 2000. In 2001, VAT on electric vehicles was abolished. The subsequent milestone was allowing electric vehicles to use bus lanes in 2003. A programme to create a network of charging stations launched in 2008, while as of 2009, persons driving an electric vehicle are not required to pay the fare for the car when travelling by ferry. In 2011, small-sized electric vehicles were permitted to park diagonally. Finally, the year 2012 saw a cross-party agreement, according to which concessions and reliefs for owners of electric vehicles would remain in place until 1 January 2018, after which date they would be gradually rescinded.

34 Sebastian Bobowski and Jan Gola, "Elektromobilność w systemie zamówień publicznych - aspekty prawne i ekonomiczne," in Prawne i ekonomiczne aspekty rozwoju elektromobilności, eds. Katarzyna Kokocińska, and Jarosław Kola (Warsaw: C.H. Beck, 2019), 57-86. 
States should therefore provide the long-term security required for private and public investment in vehicle and fuel technology, and infrastructure build-up, in order to serve the dual purpose of minimising dependence on oil and mitigating the environmental impact of transport." ${ }^{35}$ For this reason, Directive 2014/94/UE establishes an obligation for all member states to introduce national policy frameworks, which determine general and specific national goals and define actions relating to the development of the alternative fuels market. These objectives, along with the minimal requirements of the alternative fuels infrastructure that include charging stations for electric vehicles, natural gas (LNG and CNG) and hydrogen refuelling points and common technical specifications of such points, as well as user information requirements, are to be met by means of national policy frameworks in all member states.

The above means that the provisions of Union law obligate member states to undertake planning activities which on the one hand serve EUwide coordination and, on the other, well-thought-out (planned) execution at the national level..$^{36}$ At the same time, they do not dictate any solutions regarding structural organization and the modes of action which aim to

35 Recital (10), Directive 2014/94/EU.

36 On the institution of planning see e.g.: Stanisław Biernat, "Zagadnienia prawne procedury planowania gospodarczego," Krakowskie Studia Prawnicze, Year VI (1973): 37-55; Adam Chełmoński, "Instytucje administracyjnoprawne w zarządzaniu gospodarką narodową," in System Prawa Administracyjnego, vol. IV, ed. Teresa Rabska (WrocławWarsaw-Cracow-Gdańsk: Ossolineum, 1980), 449-462; Janusz Łętowski, "Miejsce i funkcje planowania w działalności administracji," SP 1983, vol. 1 (75): 3-34; Andrzej Bator, Normy planowania gospodarczego w systemie prawa (Wrocław: Wydawnictwo Uniwersytetu Wrocławskiego, 1992); Kazimierz Strzyczkowski, Administracyjnoprawne instytucje planowania (Warsaw: Wydawnictwo Uniwersytetu Warszawskiego, 1985); idem: Podstawowe problemy prawne planowania (Warsaw: Państwowe Wydawnictwo Naukowe 1990); Jerzy Supernat, Zarządzanie (Wrocław: Wydawnictwo Colonia Limited, 2005); Marek Szydło, "Planowanie indykatywne jako funkcja państwa wobec gospodarki," in Funkcje wspótczesnej administracji gospodarczej. Księga dedykowana Profesor Teresie Rabskiej, ed. Bożena Popowska (Poznań: Wydawnictwo Poznańskie, 2006), 143-162; Peter Badura, Das Planungsermessen Und die rechtsstaatliche Funktion des Allgemeinen Verwaltungsrechts, Festschrift zum 25 Jährigen Bestechen des Bayerisches Verfassungsgerichstshof (Booberg-Verlag, 1972); Eberhard Schmidt-Assmann, "Planung unter dem Grundgesetz," Die öffentliche Verwaltung, no. 16 (1974): 541-547; Marek Górski and Joanna Kierzkowska, "Strategie, plany i programy," in Prawo administracyjne materialne, vol. 7, System Prawa Admin- 
achieve the goals stated in the directive, but underline the need to ensure the capacity to carry out tasks arising from it. Much emphasis is placed on coordinated approach by designating planning acts (national policy frameworks), exchange of information and best practices between member states and focusing public support on development (Recitals 10-14, Directive 2014/94/EU). ${ }^{37}$

Directive 2014/94/EU provides that "national policy frameworks may consist of several plans, strategies or other planning documentation developed separately or in an integrated manner, or in another form, and at the administrative level decided upon by the Member States" (Recital 13), while the scope of national policy frameworks is related to the development of alternative fuels market (Article 3). Consequently, a national policy framework constitutes an act of development policy, therefore the principles and conditions of its drafting and adoption, its objective scope as well as its status in the legal order is determined by national laws. Certain authors are of the opinion that the drafting and adoption of a national policy framework relies on the provisions of the Electromobility Act. ${ }^{38} \mathrm{How}-$ ever, in the Polish legal system, the rules of according to which state policy acts (planning acts which should be construed as strategic development programming acts) are prepared and adopted are set out in a dedicated piece of legislation, namely the Act on the Principles of Development Policy (APDP) of 6 December 2006. ${ }^{39}$

istracyjnego, eds. Roman Hauser, Zygmunt Niewiadomski and Andrzej Wróbel (Warsaw: C.H. Beck, 2012), 172-220 and literature cited therein.

37 Directive 2014/94/EU asserts that it is necessary for the member states to organize actions at state level in a manner ensuring effective implementation of the policy, in accordance with the normative standard (e.g. Recitals 10, 12, 13, 14 and 65 of the Directive), further supported by the Treaty principles of subsidiarity, partnership, and proportionality, and relying on the paradigm of integrated approach to development. Concerning that issue see: Legal Challenges in EU Administrative Law. Towards an Integrated Administration, eds. Herwig Hofmann, Alexsander H. Türk (Cheltenham: Edward Elgar, 2009); Katarzyna Kokocińska, "Integrated programming in national development," Ruch Prawniczy Ekonomiczny i Socjologiczny, vol. 4 (2019): 139-149.

38 Thus for instance: Arkadiusz Ratajczak, "Komentarz do art. 43-44," in Ustawa o elektromobilności i paliwach alternatywnych. Komentarz, ed. Mariusz Swora (Warsaw: C.H. Beck, 2019), 233.

39 Consolidated text: Journal of Laws of 2019, item 1295 as amended. 
The act is concerned with the state's tasks in an area which remains fundamentally significant for other spheres of activity of public authorities, as it involves all aspects pertaining to national development and cohesion in each statutory dimension, whether objective (field- or industry-related), and spatial (territorial). The aim of development policy is to ensure continuous and sustainable development of the country, promote social, economic, regional and spatial cohesion, enhance competitiveness of the economy, and create new workplaces at national, regional, or local level. ${ }^{40}$ The legal mechanisms of development policy which the act establishes, also where it applies to public planning, should be considered a mainstay of the actions of the executive and thus superior to the remaining areas of planning. The relevance of development programming governed by the APDP derives both from the subjective scope of development policy, which includes the Council of Ministers and territorial government units, as well as from the aforementioned goal of programming, its territorial extent and absence of any limitations as to the subject matter covered by programming. Furthermore, it needs to be noted that programming documents (development strategies and programmes), adopted as part of development policy for different temporal horizons at various levels of territorial division and in various spheres of social-economic life, are to be interlinked according to the APDP. After all, actions undertaken by public entities and their administration must be harmonized to contribute to the development of the country and its cohesion. ${ }^{41}$

The national system of strategic development planning is well aligned with the legal order. ${ }^{42}$ The Act on the Principles of Development Policy expressly refers to the connection between preparation of development

40 Katarzyna Kokocińska, Prawny mechanizm prowadzenia polityki rozwoju $w$ zdecentralizowanych strukturach wtadzy publicznej (Poznań: Wydawnictwo Naukowe UAM, 2014).

41 The matter is discussed more broadly in Katarzyna Kokocińska, Prawny mechanizm prowadzenia polityki rozwoju $w$ zdecentralizowanych strukturach wtadzy publicznej (Poznań: Wydawnictwo Naukowe UAM, 2014).

42 The author deliberately refers to the analyzed process as "development programming" instead of "planning", because the former term is used by the legislator. For instance, in Article 3(a) APDP mentions undertaking initiative with respect to strategic programming, including development policy or regional policy programming; Article 9 cites EU programming periods, Article 13 states that development strategies define, in particular, 
programming acts and their implementation, between taking decisions as to how development should be designed and putting them into practice. The system of strategic programming for development policy consists of development strategies ${ }^{43}$ (whose character may be defined as indicative ${ }^{44}$ ), which are then put into practice by means of operational-implementative documents, i.e. programmes ${ }^{45}$ (aimed at influencing). Planning documents associated with development policy are functionally coupled with legal acts which provide for measures to encourage specific entities (e.g. in the domain of electromobility development) to pursue goals stated in those documents. Thus, their function is to motivate one to make certain states of affair a reality. ${ }^{46}$

State strategy for development has been laid out in a mid-term strategy of national development, i.e. Strategy for Responsible Development. Vision, Principles and Priorities of Development in the Economic, Social, and Spatial Dimensions to 2020 (with a perspective to 2030). In the latter document, the Council of Ministers assumes cohesion growth in the social, economic, environmental and territorial dimension, underlining the significance of intervention in the horizontal areas, including digitization, transport, energy, and the environment. These development

the diagnosis of situation within the scope covered by strategic programming, while Article 35(a) speaks of effective coordination of programming.

43 Pursuant to Article 9 of the Act on the Principles of Development Policy, development strategies include long-term national development strategy, mid-term national development strategy, as well as other development strategies, which represent documents defining basic conditions, goals and directions of development applicable to sectors, domains, regions or spatial development, including metropolitan and functional areas.

44 Such documents contain information on trends, challenges, concepts and scenarios of social-economic development seen in a particular perspective, thus indicating objectives, directions and priorities of development. They reflect the state of public affairs in a given sphere with respect to particular dimensions (national, territorial, or domain-specific), and determine the directions of development policy (and state intervention) which are the most likely to accomplish strategic goals.

45 The content of programmes which focus on specific objectives and actions undertaken to accomplish those (simultaneously specifying applicable sources of financing), permits them to be classified as programming documents of the influencing type.

46 Thus e.g. Marek Szydło, "Planowanie indykatywne jako funkcja państwa wobec gospodarki," in Funkcje wspótczesnej administracji gospodarczej. Księga dedykowana profesor Teresie Rabskiej, ed. B. Popowska (Poznań: Wydawnictwo Poznańskie, 2006): 143-162. 
landmarks are to be reached through key initiatives, defined as flagship and strategic projects. ${ }^{47}$ One of the major strategic projects is the Electromobility Development Programme, whose framework (as it follows from the Strategy) was to be "(...) established in the act on electromobility and other alternative fuels in transport". The programme was expected to be carried out by concentrating public means on the development of that market. According to the Council of Ministers, such a scope of action would make it possible to meet the objectives of the Electromobility Development Plan in Poland "Energy for the Future" 48 and the national policy framework for the development of alternative fuels infrastructure. ${ }^{49}$ National policy framework should be classified among development strategies referred to in Article 9(3) APDP, i.e. other development strategies defined as documents which set out basic conditions, aims, and directions of development with respect to sectors, domains (as well as regions or spatial development, including metropolitan and functional areas). The content of strategies spans e.g. the diagnosis of situation in the area to which strategic programming applies whilst allowing for environmental factors as well as spatial and territorial differences, provide forecasts of development trends in the period covered by the strategy, designate goals of development and directions of intervention along with desired benchmarks of accomplishment (with spatial and territorial differences factored in), determine the modes of reaching such goals and establish the financial framework. The above means that state policy to promote

47 See: Katarzyna Kokocińska, "Spójność działań organów władzy wykonawczej na rzecz rozwoju - na przykładzie sektora elektromobilności," in Prawne i ekonomiczne aspekty rozwoju elektromobilności, eds. Katarzyna Kokocińska, and Jarosław Kola (Warsaw: C.H. Beck, 2019), 3-18; Agnieszka Chwiałkowska and Jarosław Kola, "Wpływ ustawy o elektromobilności i paliwach alternatywnych na realizację umów na wykonywanie zadania publicznego - rozważania nad spójnością działań prawodawcy," in Prawne i ekonomiczne aspekty rozwoju elektromobilności, eds. Katarzyna Kokocińska, and Jarosław Kola (Warsaw: C.H. Beck, 2019), 87-114.

48 Document adopted by the Council of Ministers on 16 March 2017, file://C:/ Users/User/Downloads/DIT_PRE_PL\%20(1).pdf; last access: 15.8.2020.

49 Document adopted by the Council of Ministers on 29 March 2017, https:// www.gov.pl/documents/33372/436746/DRO_Krajowe_ramy_polityki_rozwoju_infrastruktury_paliw_alternatywnych.pdf/ae190d89-d530-cada-4b61-4d3c1b36a4a3; last access: 15.8 .2020$)$. 
the development of electromobility is constructed on multiple levels and takes both national and EU circumstances into consideration.

Directive 2014/94/EU stresses the necessity for coordinated and cohesive action which is founded on cooperation and partnership. Therefore, national policy framework represents a legal instrument linked to development programming acts which manifest the development policy pursued by public authorities. In addition, national policy framework constitutes an important element of the policy adopted by the EU to promote growth of the alternative fuels market in the transport sector and encourage development of the required infrastructure, which means that it is thoroughly aligned with the document system of EU development planning. After all, it needs to be emphasized that the essence of policy acts pertaining to development-oriented action lies in the statutory requirement of cohesion, which should be met by means of cooperation.

National policy framework offers an instrument thanks to which actions undertaken at the national level (involving exercise of public powers at various tiers) by diverse entities (public and private) can be cohesive, in keeping with the intentions of the Union and national legislators. The cohesion will also be retained with respect to regulations at EU level which, among other things, should be attributed to the fact that policy frameworks are developed in a procedure based on cooperation and consultation. On the other hand, the Electromobility Act merely establishes the scope of regulation of the national policy framework with regard to Union laws, and determines the procedure in which the national framework should be drafted and adopted, confining itself to stating which bodies are competent in that respect. ${ }^{50}$

50 Pursuant to Article 4 of the Electromobility Act, minister in charge of climate is responsible for affairs responsibility developing the national framework; it is then adopted by the Council of Ministers by way of resolution and promulgated in Monitor Polski, the Official Journal of the Republic of Poland. Immediately upon being approved by the Council of Ministers, the minister in charge of climate affairs conveys the framework to the European Commission. 


\section{CONCLUSIONS}

It follows from the deliberations above that planning documents play a particular role in the pursuit of development policy in the area of electromobility. The import of planning acts as measures (instruments) employed by public administration bodies lies in their content, as they indicate goals for the future and the manner in which they are to be achieved. Their legal nature is no less relevant. Planning acts include planning norms, in other words norms which specify goals and directions of action. Given the issues under discussion, it must be underlined that these norms only program actions and means to carry them out, being no more than stimuli to undertake them. By designating goals and directions of actions, the norms contained in planning acts are addressed to public administration but they do not constitute their source of competence; instead, they indicate the manner in which such bodies are to make use of the latter. ${ }^{51}$ They require implementation, which should be seen as a requirement of cooperative compliance with other legal acts. ${ }^{52}$

Planning acts also include national policy frameworks, the foremost instrument that Union and national bodies employ to influence the development of electromobility. The elements covered by the national framework in accordance with Article 43(2) of the Electromobility Act, such as assessments of the current state and future development of the alternative fuels market in the transport sector, the national goal in terms of the number of charging points installed at publicly accessible charging stations, the national goal in terms of natural gas refuelling points, actions required to accomplish those national goals, or actions to support the development of alternative fuels infrastructure in public collective transport services, are simultaneously a legal instrument applied to coordinate actions on the market of alternative fuels infrastructure. Coordination of actions of relevant bodies in the infrastructure sectors is a component of integrated approach in public policy as it serves to deliver complementary actions,

51 Thus e.g.: Eugeniusz Ochendowski, Prawo administracyjne. Część ogólna (Toruń: Towarzystwo Naukowe Organizacji i Kierownictwa, 2009).

52 Teresa Rabska, Prawo administracyjne stosunków gospodarczych (Warsaw - Poznań: Państwowe Wydawnictwo Naukowe, 1977). 
enabling the latter to be carried out (from the programming stage to execution/implementation) in a way which ensures that common strategic goals are achieved.

National policy frameworks provide an instrument which makes it possible for actions taken at various levels of public administration to be cohesive, thus conforming with the state of affairs envisioned in EU and national legislation. This cohesion on the part of public bodies engaging in development-oriented actions is a real challenge in view of the many public interests that need to be taken into account ${ }^{53}$. Integrated approach in the undertakings of public administration ${ }^{54}$ means concentrated efforts geared towards accomplishment of strategic development goals. At present, electromobility is precisely one of the areas which acquires strategic significance for development by virtue of policy acts dedicated to that issue.

\section{REFERENCES}

Bator, Andrzej. Normy planowania gospodarczego w systemie prawa. Wrocław: Wydawnictwo Uniwersytetu Wrocławskiego, 1992.

Badura, Peter. Das Planungsermessen Und die rechtsstaatliche Funktion des Allgemeinen Verwaltungsrechts, Festschrift zum 25 Jährigen Bestechen des Bayerisches Verfassungsgerichstshof. Booberg-Verlag, 1972.

Biernat, Stanisław. "Zagadnienia prawne procedury planowania gospodarczego." Krakowskie Studia Prawnicze, Year VI (1973): 37-55.

Bobowski, Sebastian, and Jan Gola. "Elektromobilność w systemie zamówień publicznych - aspekty prawne i ekonomiczne." In Prawne i ekonomiczne aspekty rozwoju elektromobilności, edited by Katarzyna Kokocińska, and Jarosław Kola, 57-86. Warsaw: C.H. Beck, 2019.

Chełmoński, Adam. "Instytucje administracyjnoprawne w zarządzaniu gospodarką narodową." In System Prawa Administracyjnego, vol. IV, edited by Teresa Rabska, 449-462. Wrocław-Warsaw-Cracow-Gdańsk: Ossolineum, 1980.

Chwiałkowska, Agnieszka, and Jarosław Kola. "Wpływ ustawy o elektromobilności i paliwach alternatywnych na realizację umów na wykonywanie zadania

53 Davies Huw, "Exploring the Impact of Policy on Road Transport in 2050," Johnson Matthey Technology Review, no. 64 (2020): 253.

54 Katarzyna Kokocińska, "Integrated programming in national development," Ruch Prawniczy Ekonomiczny i Socjologiczny, vol. 4 (2019): 139-149. 
publicznego - rozważania nad spójnością działań prawodawcy.” In Prawne $i$ ekonomiczne aspekty rozwoju elektromobilności, edited by Katarzyna Kokocińska, and Jarosław Kola, 87-114. Warsaw: C.H. Beck, 2019.

Górski, Marek, and Joanna Kierzkowska. "Strategie, plany i programy." In Prawo administracyjne materialne, vol. 7, System Prawa Administracyjnego, edited by Roman Hauser, Zygmunt Niewiadomski, and Andrzej Wróbel, 172-220. Warsaw: C.H. Beck, 2012.

Huw, Davies. "Exploring the Impact of Policy on Road Transport in 2050." Johnson Matthey Technology Review, no. 64 (2020): 252-262.

Hymel, Mona, Larry Kreiser, Janet E. Milne, and Hope Ashiabor, ed. Innovation Addressing Climate Changes Challenges. Market-based Perspectives. Critical Issues in Environmental Taxation, Volume XX, Edward Elgar Publishing Limited, 2018. Hofmann, Herwig, and Alexsander H. Türk, ed. Legal Challenges in EU Administrative Law. Towards an Integrated Administration. Cheltenham, UK Northampton, MA, USA: Edward Elgar Publishing Limited, 2009.

Lissoń, Piotr. "Zadania gminy w zakresie elektromobilności." In Prawne i ekonomiczne aspekty rozwoju elektromobilności, edited by Katarzyna Kokocińska, and Jarosław Kola, 57-86. Warsaw: C.H. Beck, 2019.

Kacperski, Celina, and Florian Kutzner. "Financial and symbolic incentives promote 'green' charging choices." Transportation Research Part F: Traffic Psychology and Behaviour, vol. 69 (2020): 151-158.

Kania, Michał. "Umowy w sprawach zamówień publicznych oraz umowy o partnerstwie publiczno-prywatnym jako forma wsparcia elektromobilności." In Prawne i ekonomiczne aspekty rozwoju elektromobilności, edited by Katarzyna Kokocińska, and Jarosław Kola, 165-190. Warsaw: C.H. Beck, 2019.

Kettner, Claudia, and Daniela Kletzan - Slaming. "Vehicle taxation in EU Member States." In Innovation Addressing Climate Changes Challenges. Market-based Perspectives, edited by Mona Hymel, Larry Kreiser, Janet E. Milne and Hope Ashiabor, Critical Issues in Environmental Taxation, Volume XX, 83-97. Cheltenham, UK Northampton, MA, USA: Edward Elgar Publishing Limited, 2018.

Kondratenko, Ivan. "Najlepsze europejskie praktyki w zakresie wspierania rozwoju elektromobilności." In Prawne i ekonomiczne aspekty rozwoju elektromobilności, edited by Katarzyna Kokocińska, and Jarosław Kola, 39-56. Warsaw: C.H. Beck, 2019.

Kokocińska, Katarzyna. "Spójność działań organów władzy wykonawczej na rzecz rozwoju (na przykładzie sektora elektromobilności).” In Prawne i ekonomiczne aspekty rozwoju elektromobilności, edited by Katarzyna Kokocińska, and Jarosław Kola, 3-16. Warsaw: C.H. Beck, 2019. 
Kokocińska, Katarzyna. "Integrated programming in national development." Ruch Prawniczy Ekonomiczny i Socjologiczny, vol. 4 (2019): 139-149.

Kokocińska, Katarzyna. Prawny mechanizm prowadzenia polityki rozwoju $w$ zdecentralizowanych strukturach wtadzy publicznej. Poznań: Wydawnictwo Naukowe UAM, 2014.

Lěvay, Petra, Ioannis Drossinos, and Christian Thiel. "The effect of fiscal incentives on market penetration of electric vehicles: A pairwise comparision of total cost of ownership." Energy Policy, vol. 105 (2017): 524-533.

Łętowski, Janusz. "Miejsce u funkcje planowania w działalności administracji." SP, vol. 1 (75) (1983).

Łuszczyk, Marcin. "Uwagi do planu rozwoju elektromobilności w Polsce." Prace Naukowe Uniwersytetu Ekonomicznego we Wroctawiu, no. 491 (2017): 274-282.

Schmidt-Assmann, Eberhard. "Planung unter dem Grundgesetz." Die Öffenfliche Verwaltung, no. 16 (1974): 541-547.

Strzyczkowski, Kazimierz. Prawo gospodarcze publiczne. Warsaw: Lexis Nexis, 2011. Strzyczkowski, Kazimierz. Podstawowe problemy prawne planowania. Warsaw: Państwowe Wydawnictwo Naukowe, 1990.

Strzyczkowski, Kazimierz. Administracyjnoprawne instytucje planowania. Warsaw: Wydawnictwo Uniwersytetu Warszawskiego, 1985.

Supernat, Jerzy. Zarzadzanie. Wrocław: Wydawnictwo Colonia Limited, 2005. Szydło, Marek. "Planowanie indykatywne jako funkcja państwa wobec gospodarki." In Funkcje wspótczesnej administracji gospodarczej. Księga dedykowana profesor Teresie Rabskiej, edited by Bożena Popowska, 143-162. Poznań: Wydawnictwo Poznańskie, 2006.

Wilson, Lindsay. Shades of Green: Electric Cars' Carbon Emissions around the Globe; Reducing the environmental impact of road construction Technical Report. ARRB Group Limited: Vermont South, Australia, 2013.

Villar Ezcurra, Marta. Cambio Climático, Fiscalidad y Energía en los Estados Unidos: Una batería de ejemplos a considerer. Cizur Menor, Navarra: Civitas, 2012.

Villar Ezcurra, Marta. "Noise pollution taxes: a possibility to explore." In Innovation Addressing Climate Changes Challenges. Market-based Perspectives, edited by Mona Hymel, Larry Kreiser, Janet E. Milne, and Hope Ashiabor, Critical Issues in Environmental Taxation, Volume XX, 113-126. Edward Elgar Publishing Limited, 2018.

Ochendowski, Eugeniusz. Prawo administracyjne. Część ogólna. Toruń: Towarzystwo Naukowe Organizacji i Kierownictwa, 2009.

Rabska, Teresa. Prawo administracyjne stosunków gospodarczych. Warsaw - Poznań: Państwowe Wydawnictwo Naukowe, 1977. 